\title{
Effects of flunixin meglumine, meloxicam, and firocoxib on the acute-phase proteins in horses following standing castration ${ }^{1}$
}

\author{
Paula A. Di Filippo ${ }^{2 *}$ (D) , Francielli P. Gobbi², Gabriela B. Lemos ${ }^{2}$, Célia R. Quirino², \\ Carla B. Martins ${ }^{3}$ and Leandro A. Fonseca ${ }^{4}$
}

\begin{abstract}
Di Filippo P.A., Gobbi F.P., Lemos G.B., Quirino C.R., Martins C.B.\& Fonseca L.A. 2021. Effects of flunixin meglumine, meloxicam, and firocoxib on the acute-phase proteins in horses following standing castration. Pesquisa Veterinária Brasileira 41:e06533, 2021. Laboratório de Clínicas e Cirurgia Veterinária, Centro de Ciências e Tecnologias Agropecuárias, Universidade Estadual do Norte Fluminense Darcy Ribeiro, Av. Alberto Lamego 2000, Campos dos Goytacazes, RJ 28013-602, Brazil. E-mail: pdf@uenf.br

Excessive infection and inflammation are the most common complications associated with castration. The objective of this study was to compare the efficacy of flunixin meglumine (FM), meloxicam (MX), or firocoxib (FX) for inflammation control after castration in horses using acute-phase proteins (APP) as markers of inflammation. Thirty healthy, unbroken, mixedbreed horses (body weight $358.62 \pm 45.57 \mathrm{~kg}$ and age $4.99 \pm 2.63$ years) were randomly ( $\mathrm{n}=10$ animals/group) allocated to receive one of three different post-castration anti-inflammatory medicines: Group 1 (FM 1.1mg/kg bwt, IV, s.i.d for 5 days); Group 2 (MX 0.6mg/kg bwt, IV, s.i.d for 5 days); and Group 3 (FX $0.1 \mathrm{mg} / \mathrm{kg}$ bwt, IV, s.i.d for 5 days). All horses were castrated in standing position, using the open technique. Serum and peritoneal APP concentrations were measured by sodium dodecyl sulfate (SDS) polyacrylamide gel electrophoresis (PAGE) and determined before castration (0), and 3, 5, 24, 48, 72, 120 and 168 hours after castration. The results were submitted to analysis of variance using the SAS statistical program, and means were compared by the Student-Newman-Keuls test $(p<0.05)$. Three animals from the MX group developed hyperthermia (with rectal temperatures of $39.8,39.3$ and $38.9^{\circ} \mathrm{C}$ on day 4, 5 and 6, respectively) and showed local clinical signs of inflammation (inguinal and excessive scrotal edema) and reluctance to walk, as well as a rigid gait of the hind limbs. The same complications were observed in one FX horse. No complications were observed among the FM animals. The castration resulted in significant changes in serum and peritoneal values of total proteins, ceruloplasmin (Cp), transferrin (Tf), albumin (Alb), haptoglobin (Hp) and $\alpha 1$-acid glycoprotein (Gp) in animals of all experimental groups. However, the animals of the MX and FX groups presented more intense acute phase response compared to the animals of the FM group. Changes in the APP were associated with the surgical trauma of castration, but the differences between groups were associated with the ability of the nonsteroidal antiinflammatory drug to control the inflammation. In conclusion, and based on the findings of acute phase proteins, flunixin is more efficient to control the magnitude of inflammation following castration as compared to meloxicam and firocoxib.
\end{abstract}

INDEX TERMS: Flunixin meglumine, meloxicam, firocoxib, proteins, horses, castration, equine, orchiectomy, inflammation, nonsteroidal anti-inflammatory agents, NSAIDs, SDS-polyacrylamide gel electrophoresis.

\footnotetext{
${ }^{1}$ Received on March 8, 2021.

Accepted for publication on March 27, 2021.

${ }^{2}$ Laboratório de Clínicas e Cirurgia Veterinária (LCCA), Centro de Ciências e Tecnologias Agropecuárias (CCTA), Universidade Estadual do Norte Fluminense Darcy Ribeiro (UENF), Av. Alberto Lamego 2000, Parque Califórnia, Campos
}

dos Goytacazes, RJ 28013-602, Brazil. E-mails: franci_gobbi@hotmail.com, gblemos.vet@gmail.com,crq@uenf.br; *Corresponding author: pdf@uenf.br

${ }^{3}$ Universidade Federal do Espírito Santo (UFES), Alto Universitário $\mathrm{s} / \mathrm{n}$, Guararema, Alegre, ES 29500-000, Brazil. E-mail: cbmvt@hotmail.com

${ }^{4}$ Universidade Federal de Viçosa (UFV), Av. Peter Henry Rolfs s/n, Campus Universitário, Viçosa, MG 36570-900, Brazil. E-mail: lenandroabfonseca@gmail.com 
RESUMO.- [Efeitos do flunixin meglumine, meloxicam e firocoxib na concentração de proteínas da fase aguda após em equinos após castração.] Infecção e inflamação excessivas são as complicações mais comuns associadas à castração. 0 objetivo deste estudo foi comparar a eficácia do flunixin meglumine (FM), meloxicam (MX) ou firocoxib (FX) no controle da inflamação após a castração em cavalos usando proteínas da fase aguda (APP) como marcadores de inflamação. Trinta equinos saudáveis $(358,62 \pm 45,57 \mathrm{~kg} ; 4,99 \pm 2,63$ anos) foram em função dos anti-inflamatórios utilizados após as castrações aleatoriamente $(\mathrm{n}=10$ animais/grupo) alocados em três diferentes grupos: Grupo 1 (FM 1,1mg/kg de peso, IV, sid por 5 dias); Grupo 2 (MX 0,6mg/kg de peso, IV, s.i.d por 5 dias); e Grupo 3 (FX 0,1mg/kg de peso, IV, s.i.d por 5 dias). Todos os cavalos foram castrados em posição quadrupedal, utilizando a técnica aberta. As concentrações de APP sérica e peritoneal foram separadas por eletroforese em gel de poliacrilamida (PAGE) com dodecil-sulfato de sódio (SDS) e determinadas no momento 0 (antes da castração) e com 3, $5,24,48,72,120$ e 168 horas após a castração. Os resultados foram submetidos à análise de variância pelo programa estatístico SAS e as médias foram comparadas pelo teste de Student-Newman-Keuls $(p<0,05)$. Três animais do grupo MX desenvolveram hipertermia (com temperatura retal de 39,8, 39,3 e $38,9^{\circ} \mathrm{C}$ nos dias 4,5 e 6 , respectivamente) e mostraram sinais clínicos locais de inflamação (edema inguinal e escrotal excessivo) e relutância em andar, bem como marcha rígida dos membros posteriores. As mesmas complicações foram observadas em um cavalo do FX. Não foram observadas complicações entre os animais do FM. Independente do grupo, a castração resultou em alterações significativas nos valores séricos e peritoneais de proteínas totais, ceruloplasmina (Cp), transferrina (Tf), albumina (Alb), haptoglobina (Hp) e glicoproteína ácida $\alpha 1(\mathrm{Gp})$. No entanto, os animais dos grupos MX e FX apresentaram resposta de fase aguda mais intensa quando comparados aos animais do FM. Alterações na resposta de fase aguda deveram-se ao trauma cirúrgico da castração, mas as diferenças entre os grupos foram associadas à capacidade do anti-inflamatório em controlar a inflamação. Em conclusão, baseado da resposta de fase aguda, o flunixin em comparação com o meloxicam e o firocoxib é mais eficiente no controle da inflamação após a castração em equinos.

TERMOS DE INDEXAÇÃO: Flunixin meglumine, meloxicam, firocoxib, proteínas, equinos, castração, cavalos, orquiectomia, inflamação, anti-inflamatório não esteroidal, AINS, eletroforese em gel de poliacrilamida.

\section{INTRODUCTION}

Castration is one of the most common surgical procedures performed on horses, and although it is considered routine elective surgery, it is a major, invasive surgery with the potential for considerable postsurgical complications and postoperative pain (Jacobsen et al. 2005). This surgery causes quite severe surgical trauma and hence results in substantial disruption of homeostasis. This partly explains why complications occur frequently after castration (Busk et al. 2010). Physiological stress (Goundasheva et al. 2005, Duran et al. 2017), inflammatory reactions (, Jacobsen et al. 2005, Busk et al. 2010, Di Filippo et al. 2014, Olson et al. 2015), pain (Love et al. 2013, Olson et al. 2015, Gobbi et al. 2020), temporary and quantitative changes of immune function and E hypovitaminosis (Demura et al. 2006) have been reported in horses after castration. These surgical stress responses are directed at allowing the body to adapt to the trauma and injured tissues to heal (Moll et al. 1995).

For castration of horses, open, closed and semi-closed techniques are used and the surgery may be performed in a standing position on a sedated animal or in a recumbent position under general anesthesia (Moll et al. 1995, Schumacher 1996). Additionally, it has been found that the secondary closure increases occurrence of excessive postoperative infection and inflammation (Hunt 1991, Moll et al. 1995). In order to optimize the surgical procedures, it is necessary to identify useful markers to evaluate the intensity of the trauma caused. Previous studies have shown that concentrations of acute phase reactants may be useful for detection of inflammatory / infectious complications after surgical procedures of horses (Jacobsen et al. 2005, Busk et al. 2010, Di Filippo et al. 2014). Acute-phase proteins are synthesized in the liver during infectious diseases and other inflammatory conditions (Pollock et al. 2005). Early recognition of excessive inflammation and infectious complications after surgery, leading to early start of therapy, reduces postoperative discomfort and facilitates recovery. Elevated serum amyloid A (SAA), haptoglobin, fibrinogen and iron have been shown to be useful for detection of inflammatory/infectious complications occurring after castration of horses (Hultén et al. 1999, Jacobsen et al. 2005, Busk et al. 2010).

Local anesthetic and non-steroidal anti-inflammatory drugs (NSAIDs) have been used to reduce stress, pain and inflammatory responses after castration of horses (Love et al. 2013, Olson et al. 2015, Abass et al. 2018). The administration of flunixin, meloxicam and firocoxib has been shown to provide extended postoperative control of pain and inflammation in horses, but these NSAIDs have not yet been compared in a single study with castrated horses or through the acute phase response. The aim of this study was to investigate the effect of three different NSAID regimens on the acute inflammatory response after castration via a scrotal approach without primary closure over a seven-day postoperative period. We hypothesized that flunixin, meloxicam and firocoxib would be similarly effective in reducing post-castration inflammation.

\section{MATERIALS AND METHODS}

Horses and study design. All animal procedures performed in this study were approved by the animal ethics committee of Darcy Ribeiro Norte Fluminense State University (protocol number 2014/327), located in Campos de Goytacazes, Rio de Janeiro state. Thirty healthy, unbroken, mixed-breed horses (body weight $358.62 \pm 45.57 \mathrm{~kg}$ and age $4.99 \pm 2.63$ years) were included in this study. The animals were allowed a minimum of 10 days of acclimatization in the hospital after arrival and were housed individually in stalls with free access to grass hay, salt and water. Before inclusion in the study, the horses were determined to be in good health on the basis of clinical examination results. Only horses with normally descended testes and no scrotal or inguinal abnormalities were included.

The horses ( $n=10$ animals/group) were randomly assigned to receive one of three different post-castration non-steroidal antiinflammatory drugs: Group 1 = flunixin meglumine - FM $1.1 \mathrm{mg} /$ $\mathrm{kg}$ bwt, IV, s.i.d for 5 days); Group 2 = meloxicam - MX $(0.6 \mathrm{mg} / \mathrm{kg}$ 
bwt, IV, s.i.d for 5 days $)$ and Group 3 = firocoxib - FX $(0.1 \mathrm{mg} / \mathrm{kg}$ bwt, IV, s.i.d for 5 days).

Surgical procedure and follow-up. All castrations were performed in standing patient position by an experienced surgeon (F.P.G.). Horses were sedated intravenously with $0.5 \mathrm{mg} / \mathrm{kg}$ of $10 \%$ xylazine (Equisedan ${ }^{\circledR}, 100 \mathrm{mg} / \mathrm{mL}$, J.A. Saúde Animal, Patrocínio Paulista, São Paulo, Brazil), and $0.036 \mathrm{mg} / \mathrm{kg}$ IV of butorphanol tartrate (Torbugesic ${ }^{\circledR}, 14.58 \mathrm{mg} / \mathrm{mL}$, Fort Dodge Saúde Animal Ltda, Campinas, São Paulo, Brazil). Approximately, 20 to 30mL of lidocaine hydrochloride without epinephrine $\left(2 \%\right.$ Xylestesin $^{\circledR}$, Cristália, Itapira, São Paulo, Brazil) was then infiltrated in and around each spermatic cord. Another $10 \mathrm{~mL}$ was infiltrated subcutaneously at the base of the scrotum on each side of the median raphae. The surgical site was cleaned and disinfected with $5 \%$ povidone iodine surgical scrub, followed by $99 \%$ isopropyl alcohol. Approximately 10 minutes after administration of the local anesthesia, the horses were castrated using an open technique (May \& Moll 2002) using Vicryl (polyglactin 910, number 2). The scrotal incisions were left open and healed by secondary intention.

Postoperative care included tetanus prophylaxis and penicillin $\mathrm{G}$ benzathine (Agrovet $^{\circledR}, 22.000 \mathrm{UI} / \mathrm{kg}$, IM, SID, 48h, 3 days). The horses were kept in stall-rest for 12-24 hours postoperatively and then let loose in an individual paddock on the following 10 days. Occurrence of complications (fever, depression, anorexia, excessive preputial and scrotal swelling, discharge, pain) was recorded.

Samples and laboratory analyses. Blood samples (approximately $5 \mathrm{~mL}$ ) were collected from the jugular vein into siliconized tubes. Serum was separated by centrifugation $(4380 \mathrm{~g}$ ) for five-minute following collection. The serum was stored at $-20^{\circ} \mathrm{C}$ until analysis. Paracentesis was performed and peritoneal fluid was collected in tubes without anticoagulant and was used for determination of total protein content. Evaluations were performed of peritoneal fluid and venous blood collected before castration (0), and 3, 5, 24, 48, 72, 120 and 168 hours after castration.

Total proteins were determined by the Biuret method (Labquest, CELM - E-225-D, BR). The serum and peritoneal acute-phase proteins were measured by sodium dodecyl sulfate (SDS) polyacrylamide gel electrophoresis (Laemmli 1970), according to the manufacturer's instructions. Molecular weights and concentrations of protein fractions were determined by computed videodensitometry (CS 9000, Shimadzu Corp., Kyoto, Japan). Reference markers (Sigma Chemical Co., St Louis, USA) were used to characterize proteins, with molecular weights of 29, 45, 66, 97.4, 116, and $205 \mathrm{kDa}$. Also, electrophoretic migration of proteins was compared with that of pure proteins, including albumin, transferrin, haptoglobin, ceruloplasmin, IgA, IgG, $\alpha 1$-antitripsin and acidic glycoprotein. All samples were analyzed in the same gel.

Statistical analysis. The results were expressed as mean \pm standard deviation (SD) and subjected to analysis of variance (ANOVA) using the SAS statistical program (SAS Institute Inc., Cary/NC). The means were compared by the Student-Newman-Keuls test $(p<0.05)$.

\section{RESULTS}

Three animals from the MX group developed hyperthermia (with rectal temperatures of $39.8,39.3$ and $38.9^{\circ} \mathrm{C}$ at 120 and 168 hours, respectively), and showed local clinical signs of inflammation (inguinal and excessive scrotal edema) and reluctance to walk, as well as a rigid gait of the hind limbs. The same complications were observed in one FX horses. No complications were observed among FM animals.
There were no significant preoperative differences among the groups in the values of total serum and peritoneal protein, ceruloplasmin, transferrin, albumin, $\alpha_{1}$ acid glycoprotein or haptoglobin; for details, see supplemental information (Table 1 and 2). After castration there was a decrease in the serum concentration of total proteins and consequent increase of proteins in the peritoneal fluid in the animals of all groups. The serum values of ceruloplasmin $(\mathrm{Cp})$, transferrin (Tf) and albumin (Alb) remained unchanged after castration, but there was an increase in the content of these proteins in the peritoneal fluid. Serum and peritoneal concentration of haptoglobin (Hp) and $\alpha 1$-acid glycoprotein (Gp) also increased after castration.

In the comparison between groups, after castration (5h-168h), the animals of the MX group had the lowest values $(p<0.05)$ of total serum and peritoneal proteins. These animals also presented the lowest values of Tf in the peritoneal fluid after castration. However, these same animals had the highest values of serum and peritoneal $\mathrm{Cp}$ (3h-168h). High $\mathrm{Hp}$ values $(p<0.05)$ were verified in the peritoneal fluid of the MX group animals at $72 \mathrm{~h}$ and $120 \mathrm{~h}$. Also, at $72 \mathrm{~h}$ and $168 \mathrm{~h}$, the animals of the MX and FX groups presented similar serum Gp values, but higher than those presented by the FM group. Opposite findings were observed in the peritoneal fluid, in which the values of Gp presented by the MX and FX animals remained the same, but lower than those presented by the FM animals. There were no differences between the serum and peritoneal values of albumin presented by the animals of the different groups.

\section{DISCUSSION}

All 30 recruited horses were castrated and completed the study. Castration took between 6 and $10 \mathrm{~min}$ and surgical conditions were scored as good in all animals. No complications related to anesthesia or surgery occurred in any animal. The reluctance to walk as well as the rigid gait of the hind limbs was due to pain due to the castration procedure. Pain restricts the movement of the animal and causes premature closure of the surgical wound, predisposing to the occurrence of more severe edema and funiculitis which may further intensify lameness (Hunt 1991). These animals have excessive scrotal edema. Flunixin also provided superior analgesia to meloxicam in horses undergoing surgery for strangulating small intestinal lesions (Naylor et al. 2014). However, the use of flunixin following surgery for small intestinal strangulating obstruction (SISO) resulted in similar levels of pain control as compared with horses treated with firocoxib (Ziegler et al. 2017).

The efficacy of NSAIDs in mechanical and inflammatory pain may differ for a variety of pharmacodynamic and pharmacokinetic reasons. Secondary pharmacologic targets, COX selectivity, and concentrations in serum or target tissues (inflamed tissue or the central nervous system) all influence NSAID efficacy (Banse \& Cribb 2017). The primary mechanism of action of NSAIDs is inhibition of cyclooxygenase (COX), thereby reducing the production of prostanoids from their arachidonic acid precursor and clinically results in a reduction of pain and inflammation (Vane \& Botting 1995, Salem et al. 2016). The two principal isoenzymes of COX (COX-1 and COX-2) are inhibited by NSAIDs to varying degrees (Ziegler et al. 2018).

In horses, flunixin is considered non-selective COX inhibitor, while meloxicam is modestly COX-2 selective and firocoxib 
is considered highly COX-2 selective (or COX-1 sparing) (Naylor et al. 2014, Ziegler et al. 2017, 2018). Although other researchers have demonstrated the efficacy of meloxicam in the control of pain and inflammation after castration of horses (Olson et al. 2015), the insufficient number of animals, the short period of time evaluated as well as the great variation in the individual behavior of the animals may have influenced the findings (Schaafsma 2009). In addition, it is known that the postoperative pain lasts for at least several days after castration. Thus, horses continued to show sings of pain and surgical site swelling on day 3 after castration, which would suggest that pain medication should be continued at least until this time (Olson et al. 2015). In the present study, 30 animals were evaluated and compared for seven days.

Castration induced a significant acute phase response (APR) in all groups of horses, lasting for at least 7 days (Table 1 and 2). Aseptic inflammation following castration is common and involves crushing of the spermatic cord with ensuing necrosis, hence causing substantial disruption of homeostasis, as well as often causing local signs of inflammation (Jacobsen et al. 2005). But is not possible during a clinical examination to distinguish clinical signs arising from the aseptic surgeryinduced inflammation from the early signs of infection, and previous studies have shown that concentrations of acute phase reactants may be useful for detection of inflammatory/ infectious complications occurring after castration of horses (Jacobsen et al. 2005, Busk et al. 2010). Acute-phase protein levels reflected the course of inflammation, and the differences observed between the groups FM, MX and FX were associated with the development of the postoperative complications described above. Elevated serum concentrations of SAA were observed three days after castration in horses that presented mild postoperative inflammation and recovered without complications (Group 1) as well as in animals that presented clinical signs of moderate to severe inflammation (Group 2). However, the concentrations returned to preoperative levels up to day 8 in the animals of Group 1, while in Group 2 the concentrations remained elevated (Jacobsen et al. 2005). These findings are similar to those observed in the present study. When compared to flunixin, the firocoxib reduced evidence of endotoxaemia at $48 \mathrm{~h}$ following surgery in horses with small intestinal strangulating obstruction (Ziegler et al. 2018). Increased APP concentrations seem to be an indicator of increased surgical risk in horses and may be useful before elective surgery for planning (Busk et al. 2010).

The physiological response to surgical trauma is a complex event, involving and promoting the interaction between numerous inflammatory mediators as well as hormonal,

Table 1. Effects of castration and flunixin meglumine (FM), meloxicam (MX) or firocoxib (FX) treatment on the total serum and peritoneal protein, ceruloplasmin and transferrin in horses

\begin{tabular}{|c|c|c|c|c|c|c|}
\hline \multicolumn{7}{|c|}{ Total protein $(\mathrm{g} / \mathrm{dL})$} \\
\hline \multirow{2}{*}{ Hours } & \multicolumn{3}{|c|}{ Serum } & \multicolumn{3}{|c|}{ Peritoneal fluid } \\
\hline & Flunixin & Meloxican & Firocoxib & Flunixin & Meloxican & Firocoxib \\
\hline 0 & $7.4 \pm 0.7^{\mathrm{a}}$ & $6.7 \pm 0.9^{\mathrm{a}}$ & $7.1 \pm 0.4^{\mathrm{a}}$ & $0.8 \pm 0.3^{\mathrm{b}}$ & $0.7 \pm 0.2^{\mathrm{b}}$ & $0.8 \pm 0.5^{b}$ \\
\hline 3 & $6.2 \pm 1.2^{\mathrm{ab}}$ & $6.0 \pm 0.3^{\mathrm{ab}}$ & $6.8 \pm 0.7^{\mathrm{ab}}$ & $0.9 \pm 0.4^{b}$ & $0.7 \pm 20.4^{b}$ & $1.6 \pm 1.1^{\mathrm{b}}$ \\
\hline 5 & $7.4 \pm 0.6^{\mathrm{Aa}}$ & $6.1 \pm 0.4^{\mathrm{Bab}}$ & $7.0 \pm 0.4^{\mathrm{Aa}}$ & $2.0 \pm 1.0^{\mathrm{Aa}}$ & $1.6 \pm 1.4^{\mathrm{Ba}}$ & $2.1 \pm 1.8^{\mathrm{Aa}}$ \\
\hline 24 & $7.1 \pm 1.6^{\mathrm{Aa}}$ & $5.7 \pm 1.9^{\mathrm{Bab}}$ & $6.5 \pm 2.3^{\mathrm{Aab}}$ & $3.1 \pm 1.5^{\mathrm{Aa}}$ & $1.7 \pm 0.7^{\mathrm{Ba}}$ & $2.5 \pm 1.6^{\mathrm{Aa}}$ \\
\hline 48 & $5.7 \pm 0.7^{\mathrm{Ab}}$ & $5.4 \pm 1.1^{\mathrm{Bb}}$ & $6.1 \pm 0.7^{\mathrm{Ab}}$ & $2.5 \pm 0.9^{\mathrm{Aa}}$ & $2.0 \pm 0.7^{\mathrm{Ba}}$ & $3.0 \pm 1.5^{\mathrm{Aa}}$ \\
\hline 72 & $5.7 \pm 1.9^{\mathrm{Ab}}$ & $5.0 \pm 1.2^{\mathrm{Bb}}$ & $6.1 \pm 1.5^{\mathrm{Ab}}$ & $2.4 \pm 1.0^{\mathrm{Aa}}$ & $1.9 \pm 0.5^{\mathrm{Ba}}$ & $2.4 \pm 1.2^{\mathrm{Aa}}$ \\
\hline 120 & $6.5 \pm 1.7^{\mathrm{Aab}}$ & $5.2 \pm 1.3^{\mathrm{Bb}}$ & $6.1 \pm 0.6^{\mathrm{Ab}}$ & $2.2 \pm 0.4^{\mathrm{Aa}}$ & $1.6 \pm 0.3^{\mathrm{Ba}}$ & $2.6 \pm 0.8^{\mathrm{Aa}}$ \\
\hline \multirow[t]{2}{*}{168} & $6.4 \pm 1.6^{\mathrm{Aab}}$ & $5.9 \pm 1.0^{\mathrm{Bab}}$ & $6.7 \pm 1.3^{\mathrm{Aab}}$ & $2.3 \pm 0.7^{\mathrm{Aa}}$ & $1.6 \pm 0.4^{\mathrm{Ba}}$ & $2.4 \pm 1.1^{\mathrm{Aa}}$ \\
\hline & \multicolumn{6}{|c|}{ Ceruloplasmin (mg/dL) } \\
\hline 0 & $33.2 \pm 26.1$ & $27.7 \pm 11.1$ & $25.7 \pm 21.2$ & $2.5 \pm 1.2^{\mathrm{b}}$ & $3.7 \pm 3.1^{\mathrm{b}}$ & $2.5 \pm 1.5^{\mathrm{b}}$ \\
\hline 3 & $24.7 \pm 15.2^{\mathrm{B}}$ & $43.5 \pm 25.1^{\mathrm{A}}$ & $20.7 \pm 9.1^{\mathrm{B}}$ & $2.0 \pm 0.8^{\mathrm{Bb}}$ & $4.1 \pm 2.7^{\mathrm{Ab}}$ & $2.2 \pm 0.3^{\mathrm{Bb}}$ \\
\hline 5 & $31.3 \pm 21.4^{\mathrm{B}}$ & $52.7 \pm 20.2^{\mathrm{A}}$ & $21.9 \pm 7.1^{\mathrm{B}}$ & $2.5 \pm 1.3^{\mathrm{Bb}}$ & $3.9 \pm 1.7^{\mathrm{Ab}}$ & $2.4 \pm 1.2^{\mathrm{Bb}}$ \\
\hline 24 & $23.3 \pm 17.9^{\mathrm{B}}$ & $56.9 \pm 28.6^{A}$ & $33.0 \pm 8.7^{\mathrm{B}}$ & $3.0 \pm 1.9^{\mathrm{Bab}}$ & $5.2 \pm 3.8^{\mathrm{Aab}}$ & $4.0 \pm 3.7^{\mathrm{Bab}}$ \\
\hline 48 & $27.0 \pm 14.9$ & $28.3 \pm 13.2$ & $27.5 \pm 19.1$ & $3.2 \pm 1.6^{\mathrm{Bab}}$ & $7.6 \pm 2.9^{\mathrm{Aab}}$ & $3.9 \pm 2.6^{\mathrm{Bab}}$ \\
\hline 72 & $31.1 \pm 21.5^{\mathrm{B}}$ & $45.4 \pm 11.9^{A}$ & $29.8 \pm 21.8^{\mathrm{B}}$ & $4.4 \pm 3.2^{\mathrm{Ba}}$ & $7.7 \pm 1.7^{\mathrm{Aa}}$ & $4.2 \pm 2.1^{\mathrm{Ba}}$ \\
\hline 120 & $34.7 \pm 10.2^{\mathrm{B}}$ & $53.2 \pm 25.0^{\mathrm{A}}$ & $37.3 \pm 28.8^{\mathrm{B}}$ & $3.9 \pm 1.8^{\mathrm{Ba}}$ & $7.0 \pm 2.5^{\mathrm{Aa}}$ & $4.5 \pm 2.8^{\mathrm{Ba}}$ \\
\hline \multirow[t]{2}{*}{168} & $33.6 \pm 13.2^{\mathrm{B}}$ & $45.2 \pm 25.3^{\mathrm{A}}$ & $26.2 \pm 17.3^{\mathrm{B}}$ & $3.6 \pm 2^{\mathrm{Bab}}$ & $6.2 \pm 3.1^{\mathrm{Aab}}$ & $2.7 \pm 0.7^{\mathrm{Bab}}$ \\
\hline & \multicolumn{6}{|c|}{ Transferrin (mg/dL) } \\
\hline 0 & $443.8 \pm 189.3$ & $523.2 \pm 141.9$ & $573.2 \pm 161.5$ & $66.9 \pm 52.7^{\mathrm{b}}$ & $60.3 \pm 32.1^{\mathrm{b}}$ & $68.7 \pm 34.3^{\mathrm{b}}$ \\
\hline 3 & $356.2 \pm 269.0$ & $465.5 \pm 147.0$ & $525.7 \pm 166.1$ & $70.4 \pm 36.3^{\mathrm{Ab}}$ & $52.1 \pm 30.6^{\mathrm{Bb}}$ & $58.0 \pm 39.1^{\mathrm{ABb}}$ \\
\hline 5 & $424.2 \pm 140.9$ & $556.4 \pm 163.6$ & $501.1 \pm 225.4$ & $135.7 \pm 55.3^{\mathrm{Aa}}$ & $65.8 \pm 28.6^{\mathrm{Bab}}$ & $113.6 \pm 81.8^{\mathrm{Aab}}$ \\
\hline 24 & $454.3 \pm 96.7$ & $506.5 \pm 183.4$ & $584.9 \pm 151.2$ & $128.1 \pm 90.7^{\mathrm{Aa}}$ & $70.0 \pm 7.3^{\mathrm{Ba}}$ & $154.1 \pm 125.7^{\text {Аа }}$ \\
\hline 48 & $541.1 \pm 143.2$ & $446.7 \pm 132.8$ & $500.5 \pm 139.4$ & $147.2 \pm 103.7^{\text {Аа }}$ & $97.9 \pm 52.9^{\mathrm{Ba}}$ & $130.6 \pm 63.4^{\text {Aa }}$ \\
\hline 72 & $384.7 \pm 150.6$ & $458.3 \pm 169.7$ & $505.1 \pm 135.7$ & $140.4 \pm 60.5^{\mathrm{Ba}}$ & $140.9 \pm 91^{\mathrm{Ba}}$ & $215.3 \pm 130.9^{\text {Аа }}$ \\
\hline 120 & $489.4 \pm 147.7$ & $511.8 \pm 198.7$ & $529.2 \pm 132.4$ & $96.9 \pm 52.3^{\mathrm{Ba}}$ & $102.1 \pm 53.7^{\mathrm{Ba}}$ & $206.8 \pm 125.8^{\mathrm{Aa}}$ \\
\hline 168 & $531.7 \pm 115.9$ & $382.6 \pm 148.3$ & $532.2 \pm 144.0$ & $136.5 \pm 70.1^{\mathrm{Ba}}$ & $115.1 \pm 39.7^{\text {Ва }}$ & $174.6 \pm 114.4^{\mathrm{Aa}}$ \\
\hline
\end{tabular}

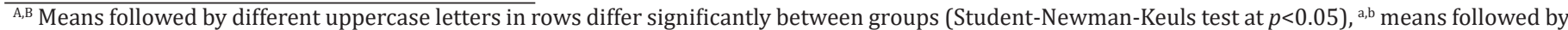
different lowercase letters in columns differ significantly between times (Student-Newman-Keuls test at $p<0.05$ ). 
metabolic and immunological processes, the ultimate goal of which is to adapt the organism to traumatized tissues and assist it in the healing process (Giannoudis 2003). Changes in concentrations of transferrin, albumin, haptoglobin and $\alpha 1$-acid glycoprotein were previously observed in horses after castration (Di Filippo et al. 2014). The castration resulted in intense surgical trauma and local inflammation which could explain in part the reason for the frequent occurrence of complications, after castration (Di Filippo et al. 2014, Busk et al. 2010). In addition, previous studies have shown that post-castration infection also alters the concentration of acutephase proteins in horses. In a clinical study, administration of penicillin over a three-day period after standing castration led to significantly lower activity of Serum Amyloid A (SAA) compared to horses without receiving penicillin (Busk et al. 2010). In the same way, animals treated with single intravenous dose of sodium penicillin $\mathrm{G}$ had a higher acute phase reaction than animals treated with intramuscular procaine penicillin daily for three days (Haucke et al. 2017). It has been suggested that concentrations of acute-phase proteins can be used to identify individuals with bacterial infection, since bacteria seem to elicit a very strong acute-phase protein response (Busk et al. 2010). But it is important to remember that acute-phase proteins are general markers of inflammation and cannot be used for a specific diagnosis (Jacobsen \& Andersen 2007). In the present study, all animals received prophylaxis with penicillin. Thus, the differences observed in the acute-phase response presented by the animals of the different groups were associated with the different NSAIDs administered after castration.

Comparative study revealed that laparotomy and ovariectomy procedures triggered an acute-phase response more intense than laryngoplasty or arthroscopy procedures (Jacobsen et al. 2009). For the authors, postoperative measurements of APP may be useful for comparing surgical trauma associated with new and established surgical techniques.

Haptoglobin is an APP that has anti-inflammatory action by binding free hemoglobin, a proinflammatory protein, within the plasma (Murata et al. 2004). Haptoglobin can be used as a clinical parameter to determine the occurrence and severity of the inflammatory response (Makimura \& Suzuki 1982, Conner et al. 1988). Thus, the greater haptoglobin concentrations in MX animals in $72 \mathrm{~h}$ and $120 \mathrm{~h}$ suggests that meloxicam treatment was not effective in reducing the magnitude of castration-induced inflammatory responses when compared to flunixin or firocoxib. On the other hand, $\mathrm{Hp}$ levels were reduced in castrated beef bulls that received oral meloxicam, but the comparison was made only between

Table 2. Effects of castration and flunixin meglumine (FM), meloxicam (MX), or firocoxib (FX) treatment on the serum and peritoneal albumin, $\alpha 1$-acid glycoprotein and haptoglobin in horses

\begin{tabular}{|c|c|c|c|c|c|c|}
\hline \multicolumn{7}{|c|}{$\operatorname{Albumin}(\mathrm{mg} / \mathrm{dL})$} \\
\hline \multirow{2}{*}{ Hours } & \multicolumn{3}{|c|}{ Serum } & \multicolumn{3}{|c|}{ Peritoneal fluid } \\
\hline & Flunixin & Meloxican & Firocoxib & Flunixin & Meloxican & Firocoxib \\
\hline 0 & $2708.1 \pm 670.7$ & $2620.1 \pm 253.2$ & $3052.3 \pm 301.4$ & $594.3 \pm 256.6^{b}$ & $419.7 \pm 401.9^{\mathrm{b}}$ & $615.8 \pm 252.1^{b}$ \\
\hline 3 & $2625.4 \pm 1066$ & $2477.8 \pm 445.2$ & $2563.5 \pm 857.9$ & $656.1 \pm 419.3^{b}$ & $510.1 \pm 303.6^{b}$ & $622.7 \pm 388.1^{b}$ \\
\hline 5 & $2748.0 \pm 1162.1$ & $2459.3 \pm 451.7$ & $2145.7 \pm 832.6$ & $1009.2 \pm 423.1^{\mathrm{a}}$ & $963.6 \pm 628.3^{a}$ & $1030.6 \pm 623 \pm 5^{a}$ \\
\hline 24 & $2978.3 \pm 782.1$ & $2455.7 \pm 621.1$ & $2484.8 \pm 583.1$ & $853.7 \pm 401.4^{\mathrm{ab}}$ & $983.2 \pm 384.6^{\mathrm{a}}$ & $1207.9 \pm 582.9^{a}$ \\
\hline 48 & $2742.1 \pm 434.2$ & $2173.9 \pm 762.5$ & $2244.1 \pm 840.6$ & $1237.3 \pm 804.3^{\mathrm{a}}$ & $1252.9 \pm 395.9^{a}$ & $1274.1 \pm 380.8^{\mathrm{a}}$ \\
\hline 72 & $2481.6 \pm 797.4$ & $2314.6 \pm 723.3$ & $2462.2 \pm 263.4$ & $1025.2 \pm 148.6^{a}$ & $1256.1 \pm 302.8^{a}$ & $1392.9 \pm 429.2^{\mathrm{a}}$ \\
\hline 120 & $2466.3 \pm 448.1$ & $2394.4 \pm 258.3$ & $2121.7 \pm 701.5$ & $791.9 \pm 203.9^{\mathrm{ab}}$ & $998.9 \pm 350.9^{a}$ & $1181.6 \pm 401.4^{\mathrm{a}}$ \\
\hline 168 & $2513.4 \pm 428.9$ & $2232.6 \pm 652.3$ & $2874.7 \pm 429.7$ & $1005.1 \pm 585.2^{\mathrm{a}}$ & $902.6 \pm 326.4^{a}$ & $1329.4 \pm 481.0^{\mathrm{a}}$ \\
\hline \multicolumn{7}{|c|}{$\alpha_{1-}$ Acid Glycoprotein (mg/dL) } \\
\hline 0 & $57.2 \pm 23.7$ & $40.2 \pm 45.3^{b}$ & $38.7 \pm 16.7^{b}$ & $9.5 \pm 8.2^{b}$ & $12.5 \pm 12.2^{\mathrm{b}}$ & $9.7 \pm 15.3^{b}$ \\
\hline 3 & $48.5 \pm 25.0$ & $51.8 \pm 12.2^{\mathrm{a}}$ & $48.0 \pm 18.3^{\mathrm{a}}$ & $25.0 \pm 23.1^{\mathrm{Aa}}$ & $11.6 \pm 8.8^{\mathrm{Bb}}$ & $11.4 \pm 15.0^{\text {Bab }}$ \\
\hline 5 & $37.5 \pm 29.3$ & $51.5 \pm 17.8^{\mathrm{a}}$ & $42.8 \pm 24.7^{a}$ & $23.1 \pm 17.2^{\mathrm{Aa}}$ & $15.1 \pm 15.4^{\mathrm{Ba}}$ & $13.7 \pm 16.9^{\mathrm{Bab}}$ \\
\hline 24 & $45.6 \pm 22.4$ & $68.9 \pm 22.3^{\mathrm{a}}$ & $49.7 \pm 16.1^{\mathrm{a}}$ & $29.8 \pm 19.2^{\mathrm{Aa}}$ & $14.6 \pm 11.2^{\mathrm{Ba}}$ & $23.9 \pm 21.1^{\mathrm{Ba}}$ \\
\hline 48 & $46.7 \pm 16.9$ & $51.9 \pm 20.6^{\mathrm{a}}$ & $52.1 \pm 32.2^{\mathrm{a}}$ & $29.4 \pm 25.7^{\mathrm{Aa}}$ & $23.3 \pm 18 .^{5 \mathrm{Ba}}$ & $23.5 \pm 11.0^{\mathrm{Ba}}$ \\
\hline 72 & $39.4 \pm 21.7^{\text {B }}$ & $55.4 \pm 35.7^{\mathrm{Aa}}$ & $65.8 \pm 26.5^{\mathrm{Aa}}$ & $32.8 \pm 12.1^{\text {Aa }}$ & $20.2 \pm 11.7^{\mathrm{Ba}}$ & $23.6 \pm 7.4^{\mathrm{Bab}}$ \\
\hline 120 & $50.6 \pm 26.4^{\mathrm{B}}$ & $68.4 \pm 12.6^{\mathrm{Aa}}$ & $61.0 \pm 11.6^{\mathrm{Aa}}$ & $37.7 \pm 9.4^{\mathrm{Aa}}$ & $22.0 \pm 18.9^{\mathrm{Ba}}$ & $31.1 \pm 23.1^{\mathrm{Ba}}$ \\
\hline 168 & $38.8 \pm 12.6^{\mathrm{B}}$ & $54.9 \pm 30.0^{\mathrm{Aa}}$ & $62.6 \pm 21.1^{\mathrm{Aa}}$ & $18.9 \pm 11.2^{\mathrm{a}}$ & $14.4 \pm 8.2^{\mathrm{ab}}$ & $14.5 \pm 11.7^{\mathrm{ab}}$ \\
\hline \multicolumn{7}{|c|}{ Haptoglobin (mg/dl) } \\
\hline 0 & $159.2 \pm 47.7^{\mathrm{b}}$ & $136.7 \pm 59.9^{b}$ & $123.1 \pm 44.9^{b}$ & $19.2 \pm 12.6^{b}$ & $23.9 \pm 19.5^{b}$ & $15.7 \pm 13.5^{b}$ \\
\hline 3 & $186.3 \pm 91.9^{\mathrm{ab}}$ & $147.1 \pm 74.8^{\mathrm{ab}}$ & $116.9 \pm 45.4^{\mathrm{ab}}$ & $28.3 \pm 14.5^{b}$ & $27.8 \pm 28.6^{b}$ & $19.3 \pm 11.1^{b}$ \\
\hline 5 & $168.2 \pm 89.1^{\mathrm{ab}}$ & $173.2 \pm 121.1^{\mathrm{ab}}$ & $132.4 \pm 55.9^{\mathrm{ab}}$ & $42.3 \pm 12.2^{\mathrm{b}}$ & $37.1 \pm 23.2^{b}$ & $33.4 \pm 28.6^{b}$ \\
\hline 24 & $216.7 \pm 88.9^{a}$ & $181.2 \pm 52.6^{a}$ & $170.7 \pm 81.2^{\mathrm{a}}$ & $65.2 \pm 74.1^{b}$ & $60.1 \pm 46.3^{b}$ & $66.9 \pm 57.5^{\mathrm{ab}}$ \\
\hline 48 & $263.1 \pm 165.6^{a}$ & $186.5 \pm 77.1^{\mathrm{a}}$ & $276.9 \pm 170.4^{a}$ & $106.8 \pm 102.9^{a}$ & $91.5 \pm 62.5^{\mathrm{a}}$ & $91.0 \pm 39.0^{\mathrm{a}}$ \\
\hline 72 & $198.6 \pm 133.7^{a}$ & $250.2 \pm 134.5^{\mathrm{a}}$ & $214.3 \pm 82.1^{\mathrm{a}}$ & $85.4 \pm 79.3^{\mathrm{Ba}}$ & $124.2 \pm 63.8^{\mathrm{Aa}}$ & $101.4 \pm 75.4^{\mathrm{ABa}}$ \\
\hline 120 & $240.8 \pm 110.2^{\mathrm{a}}$ & $251.5 \pm 81.2^{\mathrm{a}}$ & $229.1 \pm 99.3^{\mathrm{a}}$ & $57.7 \pm 43.1^{\mathrm{Bb}}$ & $75.7 \pm 36.1^{\mathrm{Ab}}$ & $70.2 \pm 48.9^{\mathrm{ABb}}$ \\
\hline 168 & $199.8 \pm 56.7^{\mathrm{a}}$ & $194.1 \pm 75.3^{\mathrm{a}}$ & $192.7 \pm 90.6^{\mathrm{a}}$ & $51.2 \pm 38.1^{b}$ & $51.2 \pm 27.9^{b}$ & $42.5 \pm 54.0^{\mathrm{b}}$ \\
\hline
\end{tabular}

by different lowercase letters in columns differ significantly between times (Student-Newman-Keuls test at $p<0.05$ ). 
animals receiving meloxicam and animals that received no anti-inflammatory therapy (Roberts et al. 2015). Elevation of serum levels of $\mathrm{Hp}$ after castration has been reported in other studies (Ken \& Goodall 1991, Di Filippo et al. 2014). The administration of carprofen reduced the concentration of Hp during banding or Burdizzo castration of bulls, indicating carprofen treatment is effective in reducing the magnitude of castration-induced inflammatory responses (Pang etal. 2006).

The reduction in Tf values in LP of MX animals could indicate the presence of subclinical peritonitis, a relatively common complication after castration (Schumacher et al. 1988, Schumacher 1996, Ziegler et al. 2018). Tf sequesters ferric ions, which can serve as substrate for several microorganisms (Murata et al. 2004). Similarly, the findings of $\mathrm{Cp}$ and $\alpha_{1}$ acid glycoprotein (Table 2) were associated with a lower ability of Mx to regulate the inflammatory response triggered by castration. Peritoneal cells produce various types of cytokines, including IL-6, and surgical procedures trigger a substantial increase in the concentration of these cytokines in the peritoneal fluid, which possibly affects the magnitude of the APR (Jacobsen et al. 2009). The development of an abdominal inflammatory process added to the local production of APP would explain the observed differences in the intensity and precocity of the changes verified in this study between the serum APR and the peritoneal APR. Produced in the abdominal cavity, close to the traumatized tissues, APP would secondarily be directed to the bloodstream and only then contribute to the systemic APR (Busk et al. 2010). Therefore, the determination of local levels of acute-phase proteins, by providing information on the inflammatory/infectious status of a site of particular interest, increases the accuracy of diagnosis (Di Filippo et al. 2019).

\section{CONCLUSIONS}

This study provides evidence that flunixin meglumine is more efficient to control the magnitude of inflammation following castration compared to meloxicam and firocoxib.

The reduction in the postoperative inflammatory response results in less pain and edema.

Acknowledgments.- This study was financed in part by the "Coordenação de Aperfeiçoamento de Pessoal de Nível Superior" (CAPES), Brazil - Finance Code 001.

Conflict of interest statement.- The authors declare no conflict of interest.

\section{REFERENCES}

Abass M., Picek S., Garzón J.F.G., Kühnle C., Zaghlou A. \& Bettschart-Wolfensberger R. 2018. Local mepivacaine before castration of horses under medetomidine isoflurane balanced anaesthesia is effective to reduce perioperative nociception and cytokine release. Equine Vet. J. 50(6):733-738. <https:// dx.doi.org/10.1111/evj.12947> <PMid:29660154>

Banse H. \& Cribb A.E. 2017. Comparative efficacy of oral meloxicam and phenylbutazone in experimental pain models in the horse. Can. Vet. J. 58(2):157-167. <PMid:28216685>

Busk P., Jacobsen S. \& Martinussen T. 2010. Administration of perioperative penicillin reduces postoperative serum amyloid A response in horses being castrated standing. Vet. Surg. 39:638-643. <https://dx.doi.org/10.1111/ j.1532-950X.2010.00704.X><PMid:20459482>

Conner J.G., Eckersall P.D., Wiseman A., Aitchison T.C. \& Douglas T.A. 1988. Bovine acute phase response following turpentine injection. Res. Vet. Sci. 44(1):82-88. <https://dx.doi.org/10.1016/0034-5288(88)90018-5> $<$ PMid:2453907>
Demura S., Takahashi K., Kawahara N., Watanabe Y. \& Tomita K. 2006. Serum interleukin-6 response after spinal surgery: estimation of surgical magnitude. J. Orthop. Sci. 11(3):241-247. <https://dx.doi.org/10.1007/ s00776-006-1002-4><PMid:16721523>

Di Filippo P.A., Gomes F.R., Mascarenhas L.S., Almeida A.J. \& Rodrigues A.B.F. 2014. Proteinograma sérico e do líquido peritoneal de equinos submetidos à orquiectomia. Ciência Rural 44(12):2221-2227. <https:// dx.doi.org/10.1590/0103-8478cr20131584>

Di Filippo P.A., Lannes S.T., Meireles M.A.D., Nogueira A.F.S. \& Quirino C.R. 2019. Concentrations of acute-phase proteins and immunoglobulins in serum and synovial fluid in clinically healthy heifers and steers. Pesq. Vet. Bras. 39(6):388-392. <https://dx.doi.org/10.1590/1678-5150-PVB-5817>

Duran M.C., Janz D.M., Waldner C.L., Campbell J.R. \& Marques F.J. 2017. Hair cortisol concentration as a stress biomarker in horses: Associations with body location and surgical castration. J. Equine Vet. Sci. 55:27-33.<https:// dx.doi.org/10.1016/j.jevs.2017.03.220>

Giannoudis P. 2003. Current concepts of the inflammatory response after major trauma: an update. Injury 34(6):397-404. <https://dx.doi.org/10.1016/ s0020-1383(02)00416-3><PMid:12767787>

Gobbi F.P., Di Filippo P.A., Mello L.M., Lemos G.B., Martins C.B., Albernaz A.P. \& Quirino C.R. 2020. Effects of flunixin meglumine, firocoxib, and meloxicam in equines after castration. J. Equine Vet. Sci. 94:103229. <https://dx.doi. org/10.1016/j.jevs.2020.103229>

Goundasheva D., Hubenov H., Kostov K. \& Karadjov T. 2005. Changes in levels of some innate immune response parameters, blood vitamins e and a in stallions, following castration. Trakia J. Sci. 3(5):1-4.

Haucke K., Kuhn M., Lübke-Becker A., Mählmann K. \& Lischer C. 2017. Two regimes of perioperative antimicrobial prophylaxis for equine castration: clinical findings, acute-phase proteins, and bacterial cultures. J. Equine Vet. Sci. 57:86-94. <https://dx.doi.org/10.1016/j.jevs.2017.07.001>

Hultén C., Tulamo R.-M., Suominen M.M., Burvall K., Marhaug G. \& Forsberg M. 1999. Anon-competetive chemiluminescence enzyme immunoassay for the equine acute-phase protein serum amyloid A (SAA) - a clinically useful inflammatory marker in the horse. Vet. Immunol. Immunopathol. 68(2/4):267-281. <https://dx.doi.org/10.1016/s0165-2427(99)00027-6> $<$ PMid:10438325>

Hunt R.J. 1991. Management of complications associated with equine castration. Comp. Cont. Educ. Pract. Vet. 13:1835-1842.

Jacobsen S. \& Andersen P.H. 2007. The acute-phase protein serum amyloid A (SAA) as a marker of inflammation in horses. Equine Vet. Educ. 19(1):3846. <https://dx.doi.org/10.1111/j.2042-3292.2007.tb00550.x>

Jacobsen S., Jensen J.C., Frei S., Jensen A.L. \& Thoefner M.B. 2005. Using serum amyloid $A$ and other acute phase reactants to monitor the inflammatory response after castration in horses - a field study. Equine Vet. J. 37(6):552-556. <https://dx.doi.org/10.2746/042516405775314853><PMid:16295934>

Jacobsen S., Nielsen J.V., Kjelgaard-Hansen M., Toelboell T., Fjeldborg J., HallingThomsen M., Martinussen T. \& Thoefner M.B. 2009. Acute phase response to surgery of varying intensity in horses: a preliminary study. Vet. Surg. 38(6):762-769. <https://dx.doi.org/10.1111/j.1532-950X.2009.00564.x> <PMid:19674420>

Ken J.E. \& Goodall J. 1991. Assessment of an immunoturbidimetric method for measuring equine serum haptoglobin concentrations. Equine Vet. J. 3(1):59-66. <https://dx.doi.org/10.1111/j.2042-3306.1991.tb02716.x> <PMid:1849813>

Love E.J., Taylor P.M., Whay H.R. \& Murrell J. 2013. Postcastration analgesia in ponies using buprenorphine hydrochloride. Vet. Rec. 172(24):365. <https://dx.doi.org/10.1136/vr.101440><PMid:23736517>

Makimura S. \& Suzuki N. 1982. Quantitative determination of bovine serum haptoglobin and its elevation in some inflammatory diseases. Japn. J. Vet. Sci. 44(1):15-21. <https://dx.doi.org/10.1292/jvms1939.44.15> <PMid:7098236> 
May K.A. \& Moll H.D. 2002. Recognition and management of equine castration complications. Comp. Cont. Educ. Pract. Vet., N. Am. 24(2):150- 162.

Moll H.D., Pelzer K.D., Pleasant R.S., Modransky P.D. \& May K.A. 1995. Survey of equine castration complications. J. Equine Vet. Sci. 15(12):522-526. <https://dx.doi.org/10.1016/S0737-0806(07)80421-7>

Murata H., Shimada N. \& Yoshioka M. 2004. Current research on acute phase proteins in veterinary diagnosis: an overview. Vet. J. 168(1):28-40. <https:// dx.doi.org/10.1016/S1090-0233(03)00119-9><PMid:15158206>

Naylor R.J., Taylor A.H., Knowles E.J., Wilford S., Linnenkohl W., Mair T.S. \& Johns I.C. 2014. Comparison of flunixin meglumine and meloxicam for post-operative management of horses with strangulating small intestinal lesions. Equine Vet. J. 46(4):427-434. <https://dx.doi.org/10.1111/ evj.12224><PMid:24372991>

Olson M.E., Fierheller E., Burwash L., Ralston B., Schatz C. \& Matheson-Bird H. 2015. The efficacy of meloxicam oral suspension for controlling pain and inflammation after castration in horses. J. Equine Vet. Sci. 35(9):724-730. <https://dx.doi.org/10.1016/j.jevs.2015.07.004>

Pang W.Y., Earley B., Sweeney T. \& Crowe M.A. 2006. Effect of carprofen administration during banding or burdizzo castration of bulls on plasma cortisol, in vitro interferon-gamma production, acute-phase proteins, feed intake, and growth. J. Anim. Sci. 84(2):351-359. <https://dx.doi. org $/ 10.2527 / 2006.842351 x><$ PMid:16424263>

Pollock P.J., Prendergast M., Schumacher J. \& Bellenger C.R. 2005. Effects of surgery on the acute phase response in clinically normal and diseased horses. Vet. Rec. 156(17):538-542. <https://dx.doi.org/10.1136/vr.156.17.538> $<$ PMid:15849343>

Roberts S.L., Hughes H.D., Burdick Sanchez N.C., Carroll J.A., Powell J.G., Hubbell D.S. \& Richeson J.T. 2015. Effect of surgical castration with or without oral meloxicam on the acute inflammatory response in yearling beef bulls. J.
Anim. Sci. 93(8):4123-4131. <https://dx.doi.org/10.2527/jas.2015-9160> <PMid:26440192>

Salem S.E., Proudman C.J. \& Archer D.C. 2016. Prevention of post-operative complications following surgical treatment of equine colic: current evidence. Equine Vet. J. 48(2):143-151. <https://dx.doi.org/10.1111/evj.12517> <PMid:26440916>

Schaafsma M.K. 2009. Assessment of pain in horses after surgical castration. Composition of a pain scale. Doctoral Dissertation, Faculty of Veterinary Medicine, Utrecht University, Netherlands.

Schumacher J. 1996. Complications of castration. Equine Vet. Educ. 8(5):254259. <https://dx.doi.org/10.1111/j.2042-3292.1996.tb01700.x>

Schumacher J., Schumacher J., Spano J.S., McGuire J., Scrutchfield W.L. \& Feldman R.G. 1988. Effects of castration on peritoneal fluid constituents in the horse. J. Vet. Intern. Med. 2(1):22-25.<https://dx.doi.org/10.1111/j.1939-1676.1988. tb01973.x><PMid:3221352>

Vane J.R. \& Botting R.M. 1995. A better understanding of antiinflammatory drugs based on isoforms of cyclooxygenase (COX-1 and COX-2). Adv. Prostaglandin Thromboxane Leukot. Res. 23:41-48. <PMid:7537433>

Ziegler A., Fogle C. \& Blikslager A. 2017. Update on the use of cyclooxygenase 2 -selective nonsteroidal anti-inflammatory drugs in horses. J. Am. Vet. Med. Assoc. 250(11):1271-1274.<https://dx.doi.org/10.2460/javma.250.11.1271> <PMid:28509650>

Ziegler A.L., Freeman C.K., Fogle C.A., Burke M.J., Davis J.L., Cook V.L., Southwood L.L. \& Blikslager A.T. 2018. Multicentre, blinded, randomised clinical trial comparing the use of flunixin meglumine with firocoxib in horses with small intestinal strangulating obstruction. Equine Vet. J. 51(3):329-335. <https://dx.doi.org/10.1111/evj.13013> <PMid:30156312> 